\title{
MODERATING ROLE OF ENVIRONMENTAL SETTINGS IN RELATIONSHIP BETWEEN PRODUCT INNOVATIVENESS AND ITS PERFORMANCE DURING THE LAUNCH
}

\author{
Indrè BRAZAUSKAITE் ${ }^{1}$, Viltė AURUŠKEVIČIENE் $\dot{2}^{2}$ \\ ${ }^{1,2}$ ISM University of Management and Economics, Lithuania \\ Corresponding author e-mail: indre.brazauskaite@stud.ism.lt
}

\begin{abstract}
The current research depicts the relationship between new product innovativeness and its performance, which was addressed in previous studies; yet the results remain contradictive with little focus on environmental settings. The paper aims to reveal the role of commercial environment towards new product performance, which allows forecasting the performance on the basis of expected settings and exploring the link between new product innovativeness and its performance in a more detailed way. In the study, moderating environmental settings are defined as a set of marketplace characteristics on market level, company commercial characteristics, and a set of sales channel characteristics on retailer's category level. Research contributes to the following areas: reveals the role of environment towards performance and allows forecasting new product performance on the basis of expected settings.
\end{abstract}

Keywords: Commercial environment, moderating effects, new product performance, product innovation, retail marketing.

JEL Classification: M11, M30, M31, O31, L81.

\section{INTRODUCTION}

Companies face different kinds of challenges when entering market with a new product, especially during launch in retail. It is illustrated by the success rates of newcomers: half of new products fail (Barczak, Griffin \& Kahn, 2009), while only $24 \%$ of innovative products commercialize successfully (Nielsen, 2014). Studies have addressed the antecedents of new product success, but results still remain inconclusive. The paper explores how the link between product innovativeness and its performance is moderated by given environmental settings. Research depicts the relationship between innovativeness and performance; however, authors (Duhamel \& Santi, 2012; Kleinknecht \& Van Der Panne, 2012; Harmancioglu, Droge \& Calantone, 2009; Lichtenhaler, 2007; Szymanski, Kroff \& Troy, 2007) indicate that the area is still unclear because of previous focus on a broader relationship, usually between innovation and company performance, with little focus on innovation performance itself or the impact of environment it commercializes in. The aim of this study is to reveal how the link between innovativeness and its performance moderated by market, retail channel specifics, and company characteristics, which jointly structures the commercial environment where new product commercializes. The relevance of this research contributes to several areas: 1) reveals the importance of the environment during new product commercialization; 2) allows forecasting

(C)2017 Indrè Brazauskaite, Viltè Auruškevičienè. This is an open access article licensed under the Creative Commons Attribution License (http://creativecommons.org/ licenses/by/4.0), in the manner agreed with De Gruyter Open. 
new product performance on the basis of expected environmental settings; 3 ) enables the managers to plan and control successful market introductions and avoid commercial failures.

\section{RESEARCH MODEL AND QUESTIONS}

We explore the following environmental settings: a set of marketplace characteristics on market level (category turnover in the market, competitive situation, and seasonality), a set of sales channel characteristics which is on retailer's category level (category role, category turnover, its competitive situation, and presence of a private label), and company commercial characteristics (company's turnover in market, marketing investment to the channel, and portfolio width). In the study, we use operationalization of innovativeness provided by Garcia \& Calantone (2002), and financial performance in value is observed as an outcome. Conceptual framework is presented in Fig. 1.

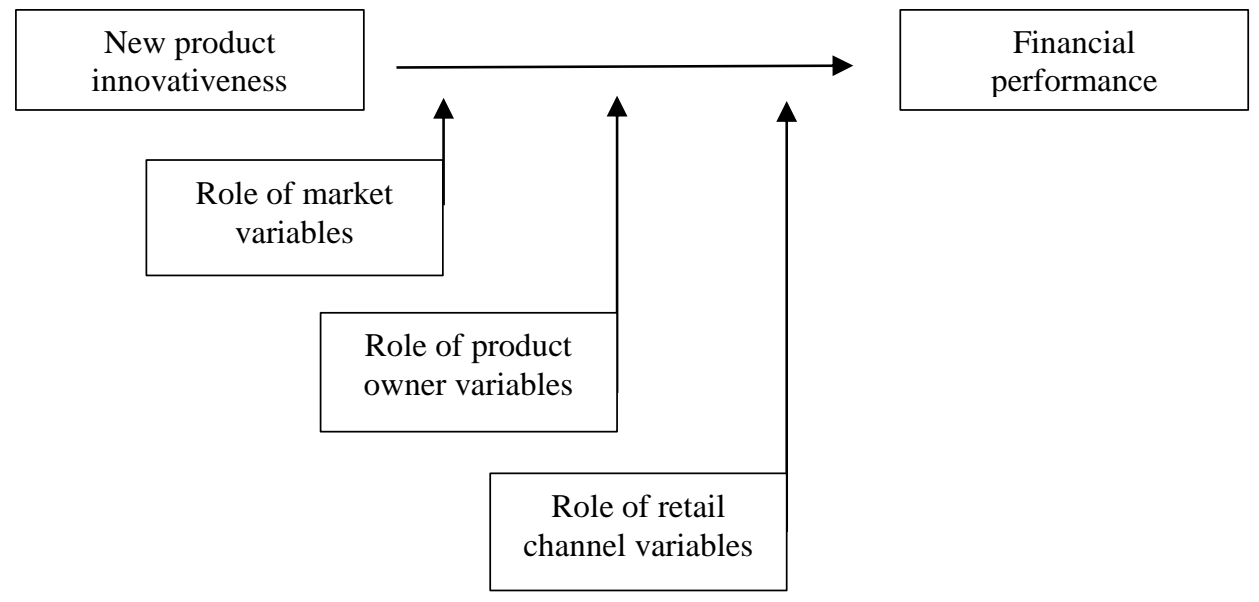

Fig. 1. Conceptual framework.

The aim is to explore the link between new product innovativeness and its performance, focusing on how this link is moderated by environmental settings. The following research questions were raised: 1) RQ1: to what extent market variables moderate the link between product innovativeness and its performance; 2) RQ2: to what extent company characteristics moderate the link between product innovativeness and its performance; 3) RQ3: to what extent retail assortment decisions moderate the link between product innovativeness and its performance.

\section{THEORETICAL BACKGROUND}

\subsection{Innovativeness}

Firth \& Narayanan (1996) define innovativeness in terms of relative difference between new and previous offerings, which is able to add value to both customer and company. Song \& Montoya-Weiss (1998) describe product innovativeness as 
the product's degree of novelty, which is often defined in relation to the company and the market. The degree of innovativeness is essential to describe, as it reveals the characteristics that are found (Robertson, 1967; Song \& Montoya-Weiss, 1998) to influence the process of new product development, especially its commercialization success. Garcia \& Calantone (2002) provide the operationalization of innovativeness on macro and micro levels as indicated in Table 1.

Table 1. Classification of innovations, based on their innovativeness (created by the authors)

\begin{tabular}{|l|c|c|c|c|c|c|}
\hline \multicolumn{1}{|c|}{$\begin{array}{c}\text { Level of } \\
\text { innovation }\end{array}$} & \multicolumn{3}{|c|}{ Macro Level } & \multicolumn{3}{c|}{ Micro Level } \\
\hline & Market & Technology & Marketing & Company & Technology & Marketing \\
\hline $\begin{array}{l}\text { Radical } \\
\text { innovations }\end{array}$ & new & new & new & new & new & new \\
\hline $\begin{array}{l}\text { Really new } \\
\text { innovations }\end{array}$ & & new & new & new & new & new \\
\hline $\begin{array}{l}\text { Discontinuous } \\
\text { innovations }\end{array}$ & & & new & new & new & new \\
\hline $\begin{array}{l}\text { Incremental } \\
\text { innovations }\end{array}$ & & & & new & new & new \\
\hline $\begin{array}{l}\text { Imitative } \\
\text { innovations }\end{array}$ & & & & new & & \\
\hline
\end{tabular}

According to Garcia \& Calantone (2002), all new products can be classified by using two levels - macro and micro, followed by two sublevels - marketing and technology. We provide a systemized table (Table 1) as a map of classification for new products. The research findings of Garcia \& Calantone are later used in our research for the identification of novelty for the analysed product innovations.

\subsection{Link between product innovativeness and its performance}

Kleinknecht \& Van Der Panne (2012) indicate that a higher level of product innovativeness carries higher uncertainties in comparison with a lower level of innovativeness. Consequently, the more radical innovations are, the less predictable in terms of performance forecasting it is. Studies reveal (Olson, Walker \& Ruekert, $1995)$ that radically innovative products confront greater commercial risks compared to less innovative products. However, some studies (Im, Nakata, Park \& Ha, 2003 Henard \& Szymanski, 2001) indicate that among many drivers of new product performance, the innovativeness as competitive advantage the product possesses, has the largest effect on performance outcomes. Although some previous studies depict relationship between innovativeness and performance, authors (Duhamel \& Santi, 2012; Kleinknecht \& Van Der Panne, 2012; Harmancioglu, Droge \& Calantone, 2009; Lichtenhaler, 2007; Szymanski, Kroff \& Troy, 2007) indicate that the area remains unclear because of primary focus on the relationship between innovation and company performance, with little focus on innovation itself, as well as its development in specific environments. 


\subsection{Role of environmental settings as moderator in relationship between innovativeness and performance}

Studies indicate that different market conditions have impact on new product performance (Carbonell \& Rodriguez, 2006; Cooper et al., 1994; Cooper \& Kleinschmidt, 1987). Cooper et al. (1994) revealed that the nature of the marketplace is one of the critical factors to have impact on new product performance in terms of its potential, growth, and competitive situation. Hultink \& Robben (1999) and Yoon \& Lilien (1985) consider two market characteristics to have impact on new product performance: introduction timing at the early stage of category life cycle, and market competitiveness. Steenkamp \& Gielens (2003 indicate that the number of brands in the category increase inner competition, thus creating greater barriers for a new brand to breakthrough. Frazier \& Lassar (1996) suggest that competitive environment may be damaging to new products as it may provoke price wars and demand higher investments to maintain the position. On the other hand, it may contribute to improvements in the company in regard to challenges and changes as timely production, competition, and quality management. Carbonell \& Rodriguez (2006) contribute to the explanation of relationship between competitive intensity and innovation performance and reveal that competition can be twofold: help to gain positional advantage, or increase the competition if there is no differentiation. Based on the findings of previous research, we hypothesize that market-related factors, namely category turnover in the market, competitive situation and seasonality, might have a moderating effect on the performance of innovations.

With the growing turbulence and instability in the marketplace, external business environment, organizational resources and capabilities become an essential tool to achieve competitive advantage (Newbert, 2007). New product launch, especially the launch of innovative products, demands certain capabilities for a company to possess, which can be considered as competitive advantage in the marketplace. Studies present a more detailed evidence related to company nature and new product performance. Namely, authors (Ali, Krapfel \& LaBahn, 1995) found a positive relationship between company size and new product performance, while Hultink \& Robben (1999) identified that the broader product assortment company has, the better market acceptance for new product is. The explanation of this relationship can be related to greater resources, market power, superior reputation and image that larger companies usually possess (Gatington, Weitz \& Bansal, 1990). Di Benedetto (1999) reveals that marketing skills and resources defined in activities as performing appropriate market research and testing, delivering quality in selling effort, service and technical support, as well as managing proper distribution channels are critical drivers for successful new product commercialization which reflects the importance of know-how the company has. Garrido-Rubio \& Polo-Redondo (2005) argue that marketing expenditures, such as ability to invest into product communication, grant a greater probability of reaching innovation's success. As highlighted, marketing expenditures are often considered as one of the most powerful tools to compete in the market or even defined as a necessary resource commitment to achieve 
performance results. Previously discussed studies reflect the significance of both competence and ability to apply it throughout various processes of new product launch. On the basis of findings provided by discussed studies, we hypothesize that product owner-related factors, such as company's turnover in market, its portfolio width and marketing investment to the sales channel, have a moderating effect on the link between product innovativeness and its performance.

With increasing power of retailers, companies need not only to consider issues that concern product development but also the best possible distribution channels to reach the consumer. According to Fornari, Grandi \& Fornari (2009), retailers "role and assortment choice effect on product owners" strategies and performance became significant. The success and failure of newly launched innovations are becoming more and more dependent on distribution channels as retailers are becoming "gate keepers" to consumers. Nilson \& Host (1987) identify the main criteria based on which the retailer decides whether to list and maintain new products in assortment, such as economic, logistic and marketing criteria. In this study, we are observing new products that already overcame the listing procedure, therefore we take only marketing criteria into consideration. Pellergrini \& Zanderight (1991) have defined marketing criteria as sales potential related factors, such as marketing investments and competitive position which can be defined in terms of category management concept, being the core of channel-related factors in this research. Studies (Dupre \& Gruen, 2004) reveal that in recent decade, category management $(\mathrm{CM})$ has become a tool for managing retail operations efficiently use of this practice helps to optimize resources and enhance business results, at the same time focusing on delivering superior value for customers. Authors highlight further benefits of category management that are the calculated use of brands to minimize intra-brand competition (Bergen, Dutta \& Shugan, 1996), the ability to cross-sell related products, participate in trade promotions (Kasulis, Morgan, Griffith and Kenderdine, 1999) and increase consumption (Wansink \& Ray, 1996). The assignment of category roles differentiates within four roles: destination, routine, occasional/seasonal, and convenience. With reference to retailer's strategy, category roles are set. Category management decisions that are taken by the retailer also include an increased emphasis on private labels (Shocker, Srivastava \& Ruekert, 1994). Private labels (PLs) are brands owned by retailers and sold exclusively in their stores. As a part of retail business, the importance of PLs in retail strategic decisions is emerging. Following the benefits, private labels are lately introduced by more and more retailers and tend to increasingly cover the number of categories. Consequently, PLs penetrate at much greater speed than manufacturers' brands (Baltas \& Argouslidis, 2007). For these reasons, the strategic importance of PL brands is getting more significant for retailers, at the same time becoming a competitive threat for manufacturers' brands. The introduction of private labels is an obvious benefit for retailers but imposes a menace for manufacturers' brands, as these activities increase rivalry not only on the retailers' shelves but in the market as well. Following recently discussed studies, we raise the hypothesis that retail category management decisions moderate the link between new product innovativeness and its performance. 


\section{MATERIALS AND METHODOLOGY}

In this research, the unit of analysis is all newly listed products, treated as product innovations. The products were introduced into a chosen Lithuanian pharmaceutical retailer assortment which owns 85 shops across the country. Later on, the performance of these new stock keeping units (SKUs) was observed in the commercial environment of chosen moderating variables. For this research, own data set was created out of several sources: innovativeness of newly listed products was evaluated using expert judgement, retail channel panel sales data was used to observe the performance of each product innovation as well as internal documents, and market data analysis was employed to create own data set for the study as indicated in Fig. 2.

Step 1. A list of new product introductions and its sales development in value during observed period (newly listed innovations sample) as dependent variable.

Step 2. Expert opinion evaluation for each newly listed innovation (level of innovativeness provided) as independent variable.

Step 3. Analysis of retailer assortment decisions and retail market data to describe moderating variables (moderating variables data set created).

Fig. 2. Procedure to data set creation.

As specified in Fig. 2, an original data pool was created using three data sources: 1) a list of product innovations was withdrawn from retailer internal data base, as well as sales performance of each item was observed for six months; 2) expert opinion evaluation (retailer's purchase or category managers who listed products to assortment were treated as experts) on each product innovation was a primary data source for the estimate of product innovativeness, based on methodology provided by Garcia \& Calantone (2002); 3) secondary data was collected representing market data and internal retailer documents', and in-depth analysis was performed to operationalize the elements of contextual environment. Each item in the sample was assigned with different variables - scale that identifies the nature of innovation, and numerical or categorical scale that defines certain characteristics of commercial environment.

The initial data set consisted of 3015 new SKUs that were listed to assortment during three-year timing and distributed across different categories. After data reduction was performed, based on chosen criteria, a sample of 1360 items, distributed through 120 categories, was left. Data reduction was performed in order to leave only "consumer products" for which a decision whether to buy was done by consumer - prescription medicines and devices that are sold under prescription or are reimbursed, were withdrawn from the sample. Items were defined as of nonreimbursed categories where consumer is taking the decision to choose a particular item with no or little influence by prescriptions, all items were merchandized in self-service, giving the ability for customer to take the decision among competitors in the category. 
Later on, the second data reduction was performed eliminating items that had missing values and were not suitable for analysis. After the second round of data reduction, 1291 items were left for further analysis which distributed across 98 categories in retailer assortment. The launch period of six months was observed as performance variable. Variation among six periods which form six alterations was analyzed. Regression analysis was performed using statistical package "Stata", and standardized $\beta$ coefficients were compared. Statistical significance was observed on levels: $*=p<0.05 ; * *=p<0.001$. Summary of findings is presented in the Conclusion part.

\section{RESULTS AND DISCUSSION}

After analyzing 1291 new product introductions with different levels of innovativeness during the period of launch, we can indicate the following conclusions. First, based on our study, the level of innovativeness of new products does not have a significant direct effect on new product performance. However, within our model, we observed that environment in general has a negative moderating effect on all levels of innovations, except type4 (incremental innovations). Secondly, we found that different groups of variables generate different moderating effects in relationship between new product innovativeness and its performance, as indicated in Table 2.

Table 2. Factors, moderating link between different levels of product innovations and sales performance, standardized $\beta$ coefficients, adjusted $\mathrm{R}$-sq $=0.11$ (created by the authors)

\begin{tabular}{|l|l|l|l|l|}
\hline \multicolumn{1}{|c|}{ Level of innovativeness } & \multicolumn{1}{|c|}{$\begin{array}{c}\text { Sales, } \\
\text { period 1 }\end{array}$} & \multicolumn{1}{c|}{$\begin{array}{c}\text { Sales, } \\
\text { period 2 }\end{array}$} & \multicolumn{1}{c|}{$\begin{array}{c}\text { Sales, } \\
\text { period 3 }\end{array}$} & \multicolumn{1}{c|}{$\begin{array}{c}\text { Sales, } \\
\text { period 4 }\end{array}$} \\
\hline Level of innovativeness & & & & \\
\hline Innovation type2 & $(-) 0.026$ & $(-) 0.161$ & $(-) 0.016$ & $(-) 0.032$ \\
\hline Innovation type3 & $(-) 0.025$ & $(-) 0.025$ & $(-) 0.036$ & $(-) 0.020$ \\
\hline Innovation type4 & 0.077 & 0.086 & 0.083 & 0.229 \\
\hline Innovation type5 & $(-) 0.030$ & $(-) 0.034$ & $(-) 0.025$ & $(-) 0.028$ \\
\hline Moderating variables, market & & & & \\
\hline Category turnover in market & $(-) 0.010$ & $(-) 0.081$ & $(-) 0.008$ & 0.012 \\
\hline Category competitiveness in market & $(-) 0.040$ & $(-) 0.069$ & $(-) 0.046$ & $(-) 0.016$ \\
\hline Product seasonality & $(-) 0.045$ & $(-) 0.035$ & $(-) 0.068$ & $(-) 0.010$ \\
\hline Moderating variables, sales channel & & & \\
\hline Category turnover in sales channel & $0.252^{*}$ & 0.267 & $0.241^{*}$ & 0.217 \\
\hline Category competitiveness in sales channel & $(-) 0.197^{*}$ & 0.186 & $(-) 0.176^{*}$ & $(-) 0.171$ \\
\hline Presence of private label in the category & $0.100^{* *}$ & 0.086 & $(-) 0.176^{*}$ & $0.088^{*}$ \\
\hline Category role, core assortment & 0.002 & $(-) 0.046$ & 0.022 & 0.007 \\
\hline Category role, destination category & $0.065^{*}$ & 0.031 & 0.059 & $0.070^{*}$ \\
\hline Category role, convenience category & $0.046^{*}$ & $0.096^{* *}$ & 0.053 & 0.023 \\
\hline Company turnover in sales channel & $0.039^{* *}$ & $0.059^{*}$ & $0.036^{* *}$ & 0.012 \\
\hline
\end{tabular}




\begin{tabular}{|l|l|l|l|l|}
\hline \multicolumn{4}{|l|}{ Moderating variables, company (product owner) } \\
\hline Company turnover in market & $0.148^{* *}$ & $0.166^{*}$ & $0.149^{* * *}$ & $0.166^{* *}$ \\
\hline Company portfolio width & $(-) 0.165^{* *}$ & $(-) 0.221^{* *}$ & $(-) 0.163^{* *}$ & $(-) 0.138^{* *}$ \\
\hline Marketing contribution to sales channel & $(-) 0.005$ & 0.006 & $(-) 0.015$ & 0.003 \\
\hline Product exclusivity to sales channel & $(-) 0.056^{*}$ & $(-) 0.035$ & $(-) 0.071^{* *}$ & $(-) 0.039$ \\
\hline$*=p<0.05 * *=p<0.01$
\end{tabular}

$*=p<0.05, * *=p<0.01$

In regard to first RQ1, we found that market variables do not have a significant moderating role and they tend to moderate the link negatively in the relationship observed, which is in contradiction to the results provided by Cooper et al. (1994) arguing that market potential and its growth are two factors contributing to new product sales performance.

Exploration of second RQ2, concerning company capabilities, revealed that company turnover as well as its portfolio width significantly contributes to sales performance. Moreover, the higher turnover of the company in the sales channel, the better performance of new product is expected. This result is in line with previous studies (Ali, Krapfel \& LaBahn, 1995; Hultink \& Robben, 1999) indicating that better acceptance of the product innovation can be associated with company size in relation to market power or superior reputation the company owns. Therefore, we can generalize that within the sample, the higher turnover the company has, the more successful commercialization is expected. However, results show portfolio width negatively moderates the link which is observed. As interpretation of this result we expect that having many products in portfolio might limit the focus to key products, which could lead to scattered marketing efforts that not necessarily generate the ultimate result. Having exclusive distribution in the sales channel, according to the data, is observed to peak at the first month of entry as well as the fourth month of entry. This result can be associated with limited distribution channels in use, which potentially leads to directing customers to a certain retailer where product is available. Following the results, it is contradictory that our analysis revealed marketing contribution not to play a significant role in the relationship between product innovativeness and its performance. However, former studies (Garrido-Rubio \& Polo-Redondo, 2005) argue that marketing expenditures is one of the predictors for innovation success. However, in our study, marketing contribution was limited to sales channel investment, differently to previous studies that evaluate overall marketing spending in the market. In addition to this finding, we could predict that marketing investment to sales channel might secure new products' position in retailer's assortment or on the shelves, and might be treated as marketing fee to the retailer.

The last RQ3, referring to the role of sales channel in moderating the link which was observed, showed the most important contribution to sales performance. First, category environment to which a new product was assigned has a significant effect on performance. Category turnover has a positive moderating effect on performance during the first and the fourth months, which could be explained by the "lift" effect by average category consumption. However, category competitiveness has a negative moderating effect during the same periods. In regard to retailer's assortment decisions, we found that the presence of a private label positively 
contributes to sales performance during the most part of periods. This finding could be explained by retailer's increased attention to the categories in which private labels exist, for example, given better visibility of the category to increase private label sales, and the "lift" effect new products experience consequently. In regard to category roles, we revealed that category role 4 (convenience category) has a significant positive moderating effect in the relationship. Convenience categories are usually used by retailers for transaction building, profit generating and image enhancing and might be associated to impulsive purchase behavior; therefore, we could assume that the products assigned to this category also experience "lift" effect because of the strategy adopted by the retailer.

Consequently, clear managerial implications follow: firstly, manufacturers may exploit "lift" effects by retailer's strategy, developing products for certain retail environments; secondly, manufacturers may oversee the potential negative moderators and address it when forming strategies and communication for new products, as well as retail teams may forecast the potential for new products in given environmental settings before listing products to assortment as well as foresee the performance of specific products.

\section{CONCLUSION AND RECOMMENDATIONS}

The paper aimed to explore the link between product innovativeness and its performance as well as its moderation by commercial environment. Previous studies (Duhamel \& Santi, 2012; Szymanski, Kroff \& Troy, 2007) had little focus on the exploration of innovation performance itself, as well as the impact of retail environment on sales performance was stated (Kleinknecht \& Van Der Panne, 2012) to be unexplored. Fornari, Grandi \& Fornari (2009) highlighted the need to study the role of retail channel in various processes, including the process of new product commercialization. In regard to moderating impact of commercial environment, a significant moderating effect of retail assortment decisions was revealed: presence of private label, category turnover and some category roles provide "lift" effect for product innovations, while competitiveness in the category gives negative effect as expected from previous studies. Investigation from product owner perspective revealed that its turnover in the market contributes to performance positively, while portfolio width in terms of the number of products forms negative effect. Research contributes to both conceptual understanding and managerial practice by revealing new aspects of product innovation management and an effect of commercial environment, especially in retail, as similar research in the area is rather limited. We would recommend several directions for future research: firstly, replica of the study in some other retail area, such as grocery, could reveal new aspects of commercial environment impact as it might differ sector to sector; secondly, the same approach could be used to compare the performance of same product innovations but across several retailers to observe the effect magnitude of commercial environments in case different retail strategies are employed. 


\section{REFERENCES}

Ali, A., Krapfel, R., \& LaBahn, D. (1995). Product innovativeness and entry strategy: impact on cycle time and break-even time. Journal of Product Innovation Management, 12, 54-69. https://doi.org/10.1111/15405885.t01-1-1210030

Baltas, G., \& Argouslidis, P. C. (2007). Consumer characteristics and demand for store brands. International Journal of Distribution and Management, 35(5), 328-341. https://doi.org/10.1108/09590550710743708

Barczak, G., Griffin, A., \& Kahn, K. (2009). Trends and drivers of success in NPD practices: Results of the 2004 PDMA Best Practices Study. Journal of Product Innovation Management, 26(1), 3-23, https://doi.org/10.1111/j.1540-5885.2009.00331

Bergen, M., Dutta, S., \& Shugan, S. (1996). Branded variants: a retail perspective. Journal of Marketing Research, 33(1), 9-19.

Carbonell, P., \& Rodriguez, A. I. (2006). The impact of market characteristics and innovation speed on perceptions of positional advantage and new product performance. International Journal of Research in Marketing, 23, 1-12. https://doi.org/10.1016/j.ijresmar.2006.01.002

Cooper, R. G., Easingwood, C. J., Edgett, S., Kleinschmidt, E. J., \& Storey, C. (1994). What distinguishes the top performing new products in financial services. Journal of Product Innovation Management, 11(4), 281299, https://doi.org/10.1111/1540-5885.1140281

Cooper, R. G., Kleinschmidt, E. J. (1987). New products: what separates winners from losers. Journal of Product Innovation Management, 4(3), 169-184, https://doi.org/10.1016/0737-6782(87)90002-6

Di Benedetto, A. C. (1999). Identifying the key success factors in new product launch. Journal of Product Innovation Management, 16, 530-544 https://doi.org/10.1111/1540-5885.1660530

Duhamel, F., \& Santi, M. (2012) Degree of innovativeness and new product performance. Technology Analysis and Strategic Management, 24(3), 253-266, https://doi.org/10.1080/09537325.2012.655411

Dupre, K., \& Gruen, T. W. (2004). The Use of Category Management Practices to Obtain a Sustainable Competitive Advantage in the Fast-Moving-Consumer-Goods Industry. Journal of Business and Industrial Marketing, 19(7), 444-459. https://doi.org/10.1108/08858620410564391

Firth, R. W., \& Narayanan, V. K. (1996). New product strategies of large, dominant product manufacturing firms: an exploratory analysis. Journal of Product Innovation Management, 13(4), 334-347. https://doi.org/10.1111/1540-5885.1340334

Fornari, D., Grandi, S., \& Fornari, E. (2009) The role of management of product innovation in retailer assortments: evidence from the Italian FMCG market. The International Review of Retail, Distribution and Consumer Research, 19(1), 29-34, https://doi.org/10.1080/09593960902781235

Frazier, G. L., \& Lassar, W. M. (1996). Determinants of distribution intensity. Journal of Marketing, 60(4), 39-51, https://doi,org/10.2307/1251900

Garcia, R., \& Calantone, R. (2002). A critical look at technological innovation typology and innovativeness terminology: a literature review. The Journal of Product Innovation Management, 19(3), 110-132, https://doi.org/10.1016/S0737-6782(01)00132-1

Garrido-Rubio, A., Polo-Redondo, Y. (2005) Tactical launch decisions: influence on innovation success/failure. Journal of Product and Brand Management, 14(1), 29-38, https://doi.org/10.1108.10610420510583725

Gatington, H., Weitz, B., \& Bansal, P. (1990). Brand introduction strategies and competitive environments. Journal of Marketing Research, 27(4), 390-401. https://doi.org/10.2307/3172625

Harmancioglu, N., Droge, C., \& Calantone, R. J. (2009). Strategic fit resources versus NPD execution proficiencies: what are their roles in determining success? Journal of the Academy of Marketing Science, 37(3), 266-282, https://doi.org/10.1007/s11747-008-0125

Henard, D. H., \& Szymanski, D. M. (2001). Why some products are more successful than others? Journal of Marketing Research, 38(3), 362-375. https://doi.org/10.1509/jmkr.38.3.362.18861

Hultink, E. J., \& Robben, H. S. J. (1999). Launch Strategy and New Product Performance: An Empirical Examination in The Netherlands. Journal of Product Innovation Management, 16(6), 545-556. https://doi.org/10.1111/1540-5885.1660029

Im, S. S., Nakata, C., Park, H., \& Ha, Y. W. (2003). Determinants of Korean and Japanese new product performance: an international and process view. Journal of International Marketing, 11(4), 81-112. https://doi.org/ 10.1509/jimk.11.4.81.20149

Kasulis, J. J., Morgan, F. W., Griffith, D. E., \& Kenderdine, J. M. (1999). Managing Trade Promotions in the Context of Market Power. Journal of the Academy of Marketing Science, 27(3), 320-332. https://doi.org/10.1177/0092070399273003

Kleinknecht, A., \& Van der Panne, G. (2012). Predicting new product sales: the post launch performance of 215 innovators. International Journal of Innovation Management, 16(2), 1-14. https://doi.org/10.1142/S136391611003544 
Lichtenthaler, U. (2007). External technology commercialization projects: objectives, processes and typology. Technology Analysis and Strategic Management, 20(4), 483-501. https://doi.org/10.1080/09537320802141452

Newbert, S. L. (2007). Empirical research on the resource-based view of the firm: an assessment and suggestions for future research. Strategic Management Journal, 28(1), 121-146. https://doi.org/10.1002/smj.573

Nielsen. (2014). Breakthrough of innovations report, European Edition, September.

Nilson, J., \& Host, V. (1987). Reseller assortment decisions criteria. Aarhus: Aarhus University Press.

Olson, E. M., Walker, O. C., \& Ruekert, R. W. (1995). Organizing for effective new product development: the moderating role of product innovativeness. Journal of Marketing, 59, 48-62.

Pellegrini, L., \& Zanderighi, L. (1997). New products manufacturers' versus retailers' decision criteria. The International Review of Retail, Distribution and Consumer Research, 1(2), 149-174. http://doi.org/10.1080/09593969100000014

Robertson, T. S. (1967). The process of innovation and the diffusion of innovation. Journal of Marketing, 31, $14-19$.

Shocker, A. D., Srivastava, R., \& Ruekert, R. (1994). Challenges and Opportunities Facing Brand Management: An Introduction to the Special Issue. Journal of Marketing Research, 31(5), 149-158.

Song, M. X., \& Montoya-Weiss, M. M. (1998). Critical development activities for really new versus incremental products. Journal of Product Innovation Management, 15(2), 124-135. https://doi.org/10.1111/1540-5885.1520124

Steenkamp J., Gielens K. (2003). Consumer and market drivers of the trial probability of new consumer packaged goods. Journal of Consumer Research, 30, 368-384, https://doi.org/10.1086/378615

Szymanski, D. M., Kroff, M. W., \& Troy, L. C. (2007) Innovativeness and new product success: insights from the cumulative evidence. Journal of the Academy of Marketing Science, 35, 35-52. https://doi.org/10.1007/s11747-006-0014-0

Wansink, B., \& Ray, M. L. (1996). Advertising Strategies to Increase Usage Frequency. Journal of Marketing, 60(1), 31-46.

Yoon, E., \& Lilien, G. L. (1985). New industrial product performance: the effect of market characteristics and strategy. Journal of Product Innovation Management, 3, 134-144. https://doi.org/10.1111/1540$\underline{5885.230134}$

\section{AUTHORS' SHORT BIOGRAPHIES}

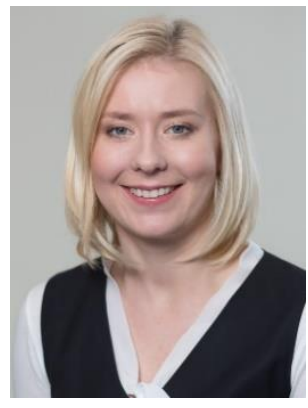

Indrè Brazauskaitė holds the B.S. degree in public health from Lithuanian University of Health Sciences, the M.S. degree in public health management from Lithuanian University of Health Sciences, and the Master's degree in business administration from Vytautas Magnus University. I. Brazauskaite is a Ph.D. candidate in strategic management and marketing at ISM University of Management and Economics. She is currently the Head of Sales at "Tamro Lithuania", one of major pharmaceutical distributors in the Baltics.

Contact e-mail: indre.brazauskaite@ stud.ism.lt

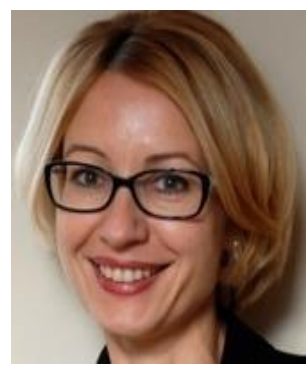

Prof. Dr. Viltė Auruškevičienè is the Vice-President for studies at ISM University of Management and Economics. V. Auruškevičienè holds a Doctor of Social Sciences degree from Kaunas University of Technology and Vytautas Magnus University. She received the Habilitation degree in marketing at Vytautas Magnus University in 2007, and obtained a pedagogical name of a Professor at ISM University of Management and Economics in 2008.

She is an International Director (Eastern Europe) of Marketing Educators' Association (MEA), a member of American Marketing Association (AMA), and an editorial board member of Baltic Journal of Management. Her research is multidisciplinary and focuses on cross-cultural behavioural issues in real and virtual environments. 